\title{
Research on New Energy Vehicle Market Penetration Rate Based on Nested Multinominal Logit Model
}

\author{
Kexin Liu *, Hong Shi, Bin Liu and Xiaorong Jian
}

check for updates

Citation: Liu, K.; Shi, H.; Liu, B.; Jian, X. Research on New Energy Vehicle Market Penetration Rate Based on Nested Multinominal Logit Model. World Electr. Veh. J. 2021, 12, 249. https://doi.org/10.3390/ wevj12040249

Academic Editor: Joeri Van Mierlo

Received: 13 September 2021 Accepted: 18 November 2021 Published: 21 November 2021

Publisher's Note: MDPI stays neutral with regard to jurisdictional claims in published maps and institutional affiliations.

Copyright: (c) 2021 by the authors. Licensee MDPI, Basel, Switzerland. This article is an open access article distributed under the terms and conditions of the Creative Commons Attribution (CC BY) license (https:// creativecommons.org/licenses/by/ $4.0 /)$.
China Automotive Technology and Research Center, No.68, East Xianfeng Road, Dongli District, Tianjin 300300, China; shihong@catarc.ac.cn (H.S.); liubin@catarc.ac.cn (B.L.); jianxiaorong@catarc.ac.cn (X.J.)

* Correspondence: liukexin@catarc.ac.cn

\begin{abstract}
This article uses the NMNL (nested multinominal logit) model to analyze the impact of different policies on the cost of owning a vehicle by a consumer and discusses the changes in the share of various fuel-driven types of passenger vehicles that may be brought by different policy portfolios. This article also considers the differences in the development of various technical routes, conducts the nested classification calculation of different models, divides the differences in product preferences and obtains the market share results that are more in line with the market development status, providing a basis for the formulation of policies related to new energy vehicles. The study found that the popularization of NEVs requires more cost-reducing measures. As policies that consumers can perceive, consumers are more sensitive to fiscal and taxation policies than other types of policies. Based on the calculation of policy effects, this article recommends a policy plan to gradually impose vehicle purchase tax on NEVs after 2024, increase the fuel tax rate in stages after 2025, and impose an excise tax on BEVs and FCEVs after 2030. The plan can guarantee the stability of support for NEVs and the gradual reduction of financial investment.
\end{abstract}

Keywords: passenger vehicle; market development; prediction; policy

\section{Introduction}

Since the State Council issued the "Energy-saving and New Energy Vehicle Industry Development Plan (2012-2020)" in 2012 [1], China has always adhered to the strategic orientation of blade electric driven. In this context, China has made great achievements in the development of the new energy vehicle industry and has become an important force in promoting the transformation of the automobile industry in the world. During the past 10 years, a set of policies have been developed, including technological innovation policy [2-5], macro comprehensive policy [1,6-8], subsidy $[9,10]$ and tax incentive policy [11-14], infrastructure policy [15-19], industry management policy [20-22], and transport policy [23-25]. Figure 1 summarizes and shows the supporting policy system for China's NEV industry.

It should be noted that New Energy Vehicles (NEVs) are unique terms used in China. It refers to vehicles that adopt new power systems and rely entirely or mainly on new energy sources, including Battery Electric Vehicles (BEVs), Plug-in Hybrid Electric Vehicles (PHEVs) and Fuel Cell Electric Vehicles (FCEVs).

Among them, the purchase subsidies and tax incentives for NEVs are important policies to promote the development of the NEV market, and they are also the main policies that consumers can perceive. In 2009, China introduced the purchase subsidy policy for the first time, mainly for vehicles in the public service sector. In 2010, the subsidy policy for private purchases of NEVs began. As the cost of NEVs declines, the amount of subsidies gradually declines. In order to encourage the improvement of technology level, the technical requirements are gradually improved. Figure 2 shows the development of China's NEVs purchase subsidy policy. 


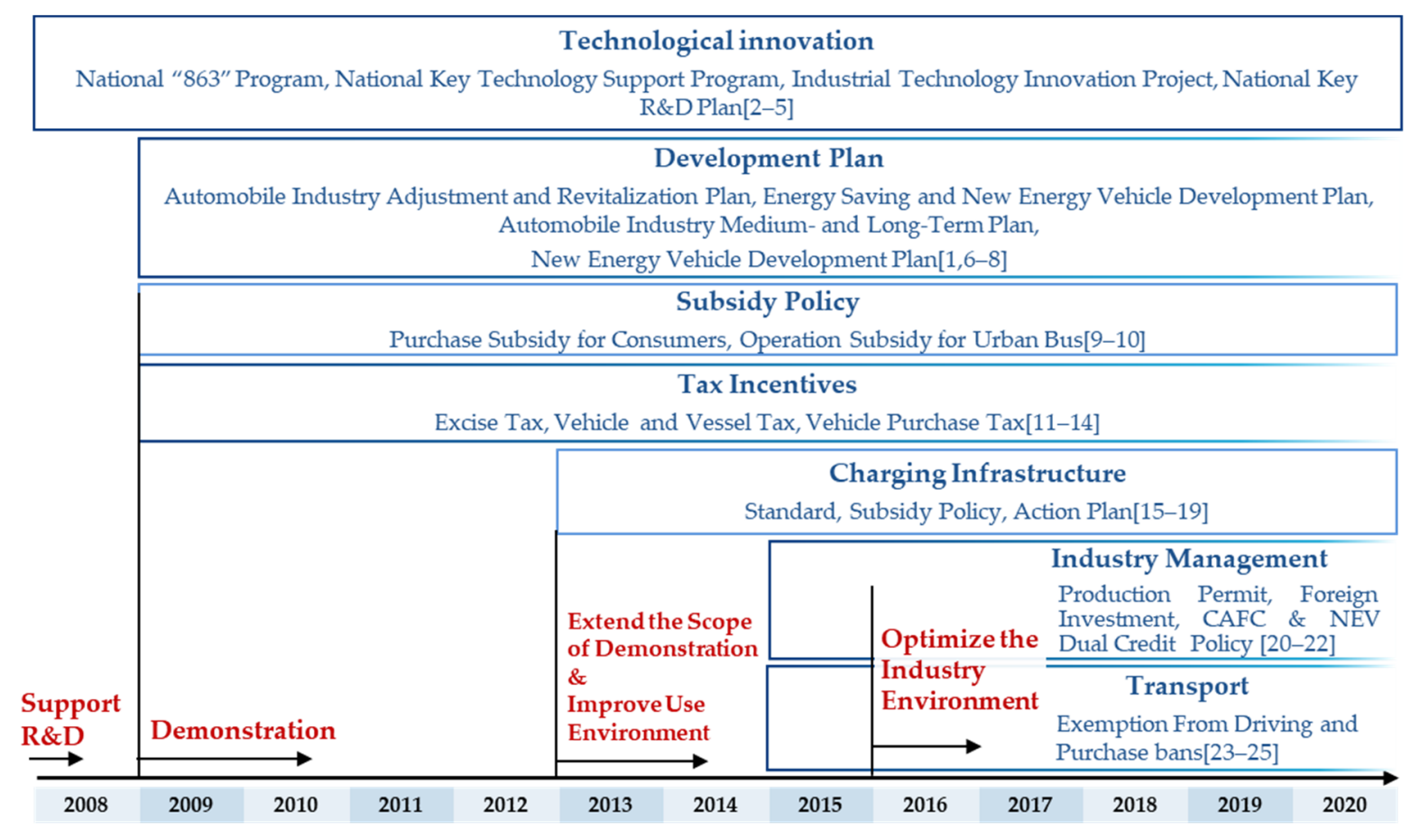

Figure 1. China's NEV industry-supporting policy system.

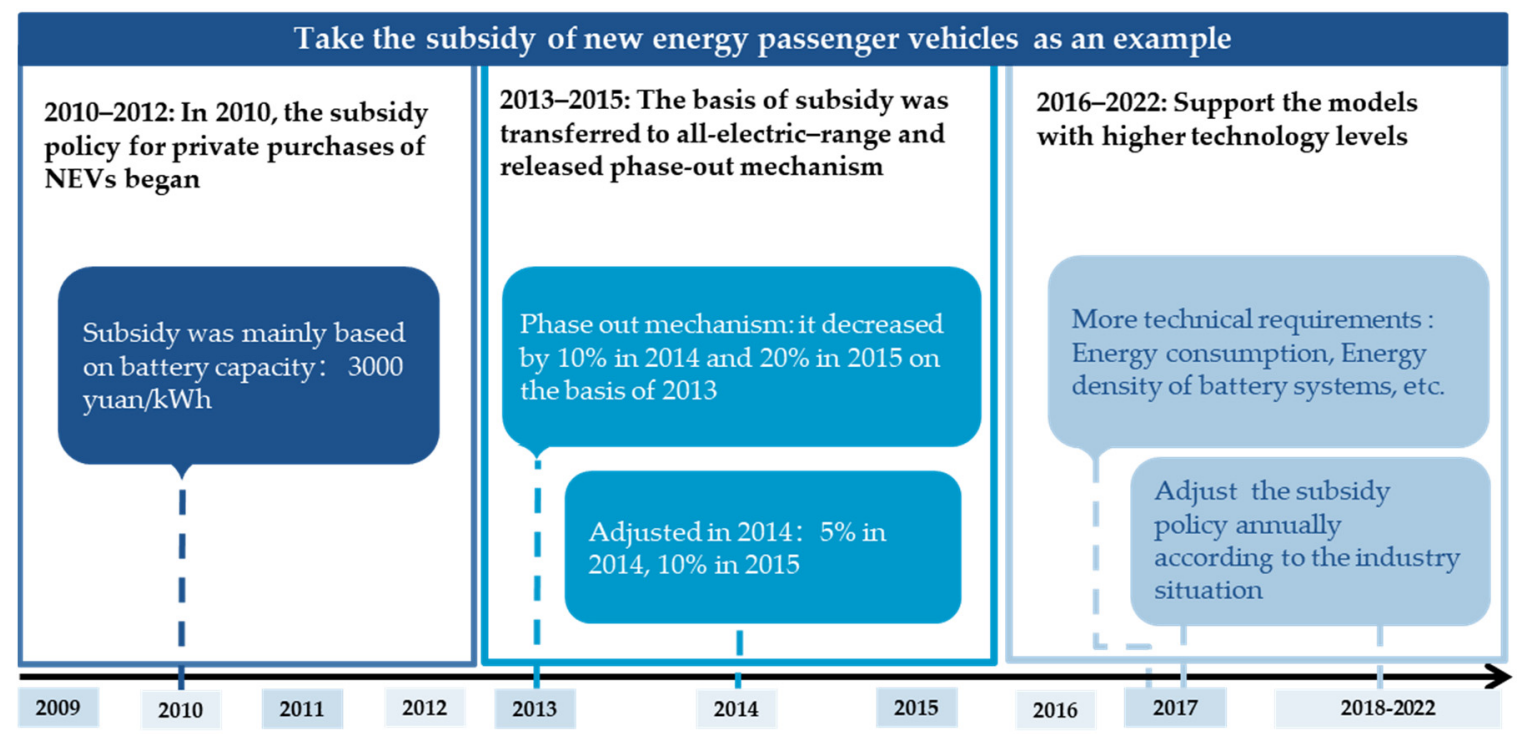

Figure 2. China's NEVs purchase subsidy policy.

The NEVs tax incentives include exemption of excise tax, purchase tax and vehicle and vessel tax. Table 1 shows tax incentives for vehicle manufacturers, consumers, and vehicle owners.

The year 2020 coincides with the expiration of the previous stage of the NEV industry development plan. At the same time, the outbreak of the COVID-19 epidemic and a further decline in subsidy policies [26] have also increased the uncertainty in the market. In order to stabilize the expectations of the industry and society, the Ministry of Industry and Information Technology took the lead in formulating the "New Energy Vehicle Industry Development Plan (2021-2035)" [8], which set a goal that the sales of NEVs will account for $20 \%$ by 2025 . However, NEVs are affected by technology, cost, policy and other aspects, 
so it is necessary to further study how to predict the market share of different fuel-driven types of vehicles in 2021-2035 in a scientific manner.

Table 1. China's NEVs tax incentives.

\begin{tabular}{|c|c|c|c|}
\hline \multicolumn{2}{|c|}{ Tax Type } & \multirow{2}{*}{\begin{tabular}{l}
\multicolumn{1}{c}{ Tax Rate } \\
- $\quad$ 1-40\% depending on \\
engine displacement for \\
passenger vehicles \\
- $\quad$ \% for medium and light \\
commercial vehicles
\end{tabular}} & \multirow{2}{*}{$\begin{array}{l}\text { Exemption Policy } \\
\text { Battery electric passenger vehicles } \\
\text { and fuel cell passenger vehicles } \\
\text { do not belong to the scope of } \\
\text { excise tax }\end{array}$} \\
\hline $\begin{array}{c}\text { Excise tax } \\
\text { (Production/import stage) }\end{array}$ & $\begin{array}{l}\text { Vehicle } \\
\text { manufacturers/importers } \\
\text { pay the tax at the point of } \\
\text { production/import for } \\
\text { onetime }\end{array}$ & & \\
\hline $\begin{array}{c}\text { Purchase tax } \\
\text { (Purchase stage) }\end{array}$ & $\begin{array}{l}\text { Consumers pay the tax at } \\
\text { the point of purchase for } \\
\text { onetime }\end{array}$ & - $10 \%$ of vehicle price & $\begin{array}{l}\text { BEV, PHEV, and FCEV are exempt } \\
\text { from purchase tax to the end } \\
\text { of } 2022\end{array}$ \\
\hline $\begin{array}{l}\text { Vehicle and Vessel tax } \\
\text { (Ownership stage) }\end{array}$ & $\begin{array}{l}\text { Owners of vehicle pay the } \\
\text { tax per year }\end{array}$ & $\begin{array}{l}\text { 60-5400 RMB depending } \\
\text { on cylinder capacity for } \\
\text { passenger vehicles } \\
\text { - } 480-1440 \text { RMB for each } \\
\text { bu } \\
\text { - } 16-120 \text { RMB per ton for } \\
\text { freight vehicles }\end{array}$ & $\begin{array}{l}\text { Battery electric passenger vehicles } \\
\text { and fuel cell passenger vehicles } \\
\text { do not belong to the scope of tax, } \\
\text { and other NEVs are exempt }\end{array}$ \\
\hline
\end{tabular}

As the passenger vehicle market is quite different from the commercial vehicle market, the passenger vehicle market is more relevant to consumer decisions. Therefore, this article focuses on the new energy passenger vehicle market, uses an NMNL model and combines with cost, sales and other data to simulate the purchase behavior of consumers and analyze the market share of different fuel-driven types of passenger vehicles in the future. In addition, because consumers can mainly perceive subsidies and tax policies when purchasing, this article also focuses on analyzing the effects of subsidies and tax policies. It quantifies and splits the various policies in different links, and studies the changes in the market structure of passenger vehicles that may be brought by different policy portfolios.

\section{Research Methods}

\subsection{Utility Maximization}

The Discrete Choice Model (DCM) is one of the commonly-used methods to study consumers' decision-making behavior. This model describes the consumer's choice behavior and consideration factors under different alternatives. The derivation of DCM is usually based on random utility maximization (RUM), which believes that consumer $n$ will follow two basic principles: (1) Consumer $n$ can obtain a certain utility $U_{n j}$ in any decision $j$ and the utility $U_{n j}$ can be divided into two parts: the observable utility determination term $V_{n j}$ and the unobservable utility variation term $\varepsilon_{n j}$. $U_{n j}=V_{n j}+\varepsilon_{n j}$. (2) When consumer $n$ is involved in the decision-making process, if and only if $U_{n i}>V_{n j}$ and $\forall j \neq i$, the alternative $i$ is chosen. That is, the consumer will choose the decision-making scheme that maximizes the utility [27].

\subsection{MNL Model}

The MultiNominal Logit (MNL) model is the most widely used model among all the discrete choice models. The model believes that consumers' decision-making schemes are mutually exclusive and the decision-making schemes considered by consumers are comprehensive. Based on the random utility theory, assuming that $V_{n j}$ and $\varepsilon_{n j}$ are independent 
of each other and the probability variable $\varepsilon i$ obeys the Gumbel distribution, the probability that consumer $n$ chooses the scheme $i$ is derived as follows:

$$
P_{n i}=\frac{e^{V_{n i}}}{\sum_{j=1}^{C_{n}} e^{V_{n j}}}
$$

where:

$n$ - a certain consumer;

$j$ - a certain decision;

$C j-$ a set of decision-making schemes; and

$V_{n i}$-fixed utility item of decision $i$ chose by consumer $n$.

\subsection{NMNL Model}

The independence of irrelevant alternatives (IIA) among all decision-making schemes is a necessary and sufficient condition for the establishment of the MNL model. When there is a correlation among all decision-making schemes, it is recommended to consider choosing an NMNL to construct a tree-shaped decision-making structure, dividing the complete set of decisions into multiple subsets and including the highly-relevant schemes into the same subset. That is, the consumer's decision-making process is divided into two stages: firstly, choose the decision subset with the greatest utility; and then, choose the decision with the greatest utility, namely:

The probability that consumer $n$ chooses the $i$-th subset among the $m$ subsets of the complete set is:

$$
P_{n h}=\frac{\sum_{j \in h_{i}} e^{V_{n j}}}{\sum_{r=1}^{m} \sum_{j \in h_{r}} e^{V_{n j}}}
$$

The probability that consumer $n$ chooses the decision $k$ among the $l_{i}$ decision schemes in the subset $h_{i}$ is:

$$
P_{n k \mid h}=\frac{e^{V_{n k}}}{\sum_{j=1}^{l_{i}} e^{V_{n j}}}
$$

The probability that consumer $n$ chooses decision $k$ is:

$$
P_{n k}=P_{n h_{i}} \times P_{n k \mid h_{i}}
$$

\subsection{Review of Market Forecast Models}

A recent study based on an empirical survey states that more than $80 \%$ of respondents considered purchase costs as crucial when considering the purchase of NEVs [28]. In addition to the purchase cost, other socioeconomic factors are involved in the decision-making process, such as environmental awareness, the number of charging stations, mobility needs, subjective preferences, and incentives [29,30]. Incentives can be divided into financial incentives and non-financial incentives. Financial incentives have a great influence on consumers' purchase decisions, including purchase subsidy, excise tax, value-added tax and vehicle purchase tax [31,32]. Non-financial incentives, such as HOV lane access and free parking, have typically not been found to have a significant impact on the purchase of NEVs $[33,34]$.

Logit models are a commonly used means for modeling the probabilistic preference of consumers, while discrete choice models calculate the probability of a specific product being chosen among alternatives under the influence of these preferences. The two different logit models used in the automotive consumer preference literature are the multinomial logit model (MNL), which represents the probability of choosing an alternative over all alternatives [35-37], and the nested multinomial logit model (NMNL), which represents the probability of choosing an alternative over the nest alternative [38-40].

This article summarizes recent studies (2016-2020) on the market diffusion of NEVs and compares the models and attributes considered in these studies in Table 2. The 
article determines that costs and financial incentives are the main factors affecting the market diffusion of NEVs. The MNL model and the NMNL model are common methods for modeling the probabilistic preference of consumers. However, the above-mentioned studies did not focus on the effect of China's financial incentive policies. This article will focus on financial incentives and study the changes in the market structure of passenger vehicles that may be brought by different policy portfolios.

Table 2. Recent studies (2016-2020) on the market diffusion of NEVs.

\begin{tabular}{|c|c|c|c|c|c|c|c|c|}
\hline \multirow[b]{2}{*}{ Author } & \multirow[b]{2}{*}{ Model } & \multirow[b]{2}{*}{ Country } & \multicolumn{4}{|c|}{ Cost } & \multicolumn{2}{|c|}{ Incentive } \\
\hline & & & $\begin{array}{l}\text { Purchase } \\
\text { Cost }\end{array}$ & $\begin{array}{l}\text { Fuel } \\
\text { Cost }\end{array}$ & $\begin{array}{l}\text { Convenience } \\
\text { Cost }\end{array}$ & $\begin{array}{l}\text { Other } \\
\text { Cost }\end{array}$ & $\begin{array}{l}\text { Financial } \\
\text { Incentive }\end{array}$ & $\begin{array}{l}\text { Nonfinancial } \\
\text { Incentive }\end{array}$ \\
\hline Ardeshiri and Rashidi (2020) [41] & NMNL & Australia & & & $\sqrt{ }$ & & & \\
\hline Gong et al. (2020) [42] & NMNL & Australia & $\sqrt{ }$ & $\checkmark$ & $\sqrt{ }$ & $\sqrt{ }$ & & $\sqrt{ }$ \\
\hline Abotalebi et al. (2019) [43] & NMNL & Canada & $\sqrt{ }$ & 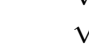 & $\sqrt{ }$ & $\sqrt{ }$ & $\sqrt{ }$ & $\sqrt{ }$ \\
\hline Axsen et al. (2016) [44] & NMNL & Canada & $\sqrt{ }$ & $v$ & & & & \\
\hline Ferguson et al. (2018) [45] & NMNL & Canada & $\sqrt{ }$ & $\sqrt{v}$ & $\sqrt{ }$ & $\sqrt{ }$ & $\sqrt{ }$ & $\sqrt{ }$ \\
\hline Kormos et al. (2019) [46] & NMNL & Canada & $\sqrt{ }$ & $\mathrm{v}$ & $\sqrt{ }$ & & & \\
\hline Huang and Qian (2018) [47] & NL & China & $\sqrt{ }$ & $\sqrt{v}$ & $\sqrt{ }$ & $\sqrt{ }$ & & $\sqrt{ }$ \\
\hline Ma et al. (2019) [48] & MNL & China & $\sqrt{ }$ & & $\sqrt{ }$ & $\sqrt{ }$ & $\sqrt{ }$ & $\sqrt{ }$ \\
\hline Qian et al. (2019) [49] & MNL & China & $\sqrt{ }$ & $\checkmark$ & $\sqrt{ }$ & & & \\
\hline Wang et al. (2017) [50] & MNL & China & $\sqrt{ }$ & & & $\sqrt{ }$ & $\sqrt{ }$ & $\sqrt{ }$ \\
\hline Hackbarth et al. (2016) [51] & NMNL & Germany & $\sqrt{ }$ & 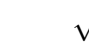 & $\sqrt{ }$ & $\sqrt{ }$ & & $\sqrt{ }$ \\
\hline Danielis et al. (2020) [52] & MNL & Italy & $\sqrt{ }$ & 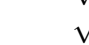 & $\sqrt{ }$ & $\sqrt{ }$ & & $\sqrt{ }$ \\
\hline Orlov et al. (2019) [53] & MNL & Norway & $\sqrt{ }$ & $\mathrm{v}$ & & & & \\
\hline Choi et al. (2018) [54] & MNL & $\begin{array}{l}\text { South } \\
\text { Korea }\end{array}$ & $\sqrt{ }$ & $\mathrm{v}$ & $\sqrt{ }$ & & & \\
\hline Langbroek et al. (2016) [55] & MNL & Sweden & $\sqrt{ }$ & & & $\sqrt{ }$ & $\sqrt{ }$ & $\sqrt{ }$ \\
\hline Cirillo et al. (2017) [56] & MNL & USA & $\sqrt{ }$ & $\checkmark$ & & & & \\
\hline
\end{tabular}

\section{Model Building}

\subsection{Research Ideas and Selection of Indicators}

Based on the NMNL model, this article predicts the probability of the consumers' choice of each vehicle model by judging the model indicators and influencing factors. Then, the market share of various fuel-driven types of passenger vehicles and the market penetration rate of NEVs under different policy backgrounds. The research assumes that consumers mainly consider the purchase price, speed of depreciation, fuel cost incurred during use and convenience of charging and refueling of each model in the process of purchasing passenger vehicles and classify them into four categories, namely: purchase cost, depreciation cost, fuel cost and convenience cost $[57,58]$. At the same time, various costs are subdivided, while taxation policies related to refined oil consumption tax, purchase tax and value-added tax are introduced [59]. Combining with the requirements for quantitative analysis and comparability of indicators in the model, the model input and process are shown in Figure 3.

Purchase cost: It refers to the actual purchase cost that should be paid by the consumer for the model. The cost of basic components of each model, cost of the battery, motor and electronic controller, cost of the engine, transmission and exhaust system and R\&D costs are used as the manufacturer suggested retail price (MSRP). At the same time, it is necessary to consider the decline in battery cost caused by the advancement of battery technology, decrease in R\&D expense for a single vehicle caused by the increase in the sales of NEVs, increase in the cost of fuel vehicle engines caused by the tightening of fuel consumption regulations and the changes in purchase subsidy, purchase tax rate and value-added tax rate in the coming years. 


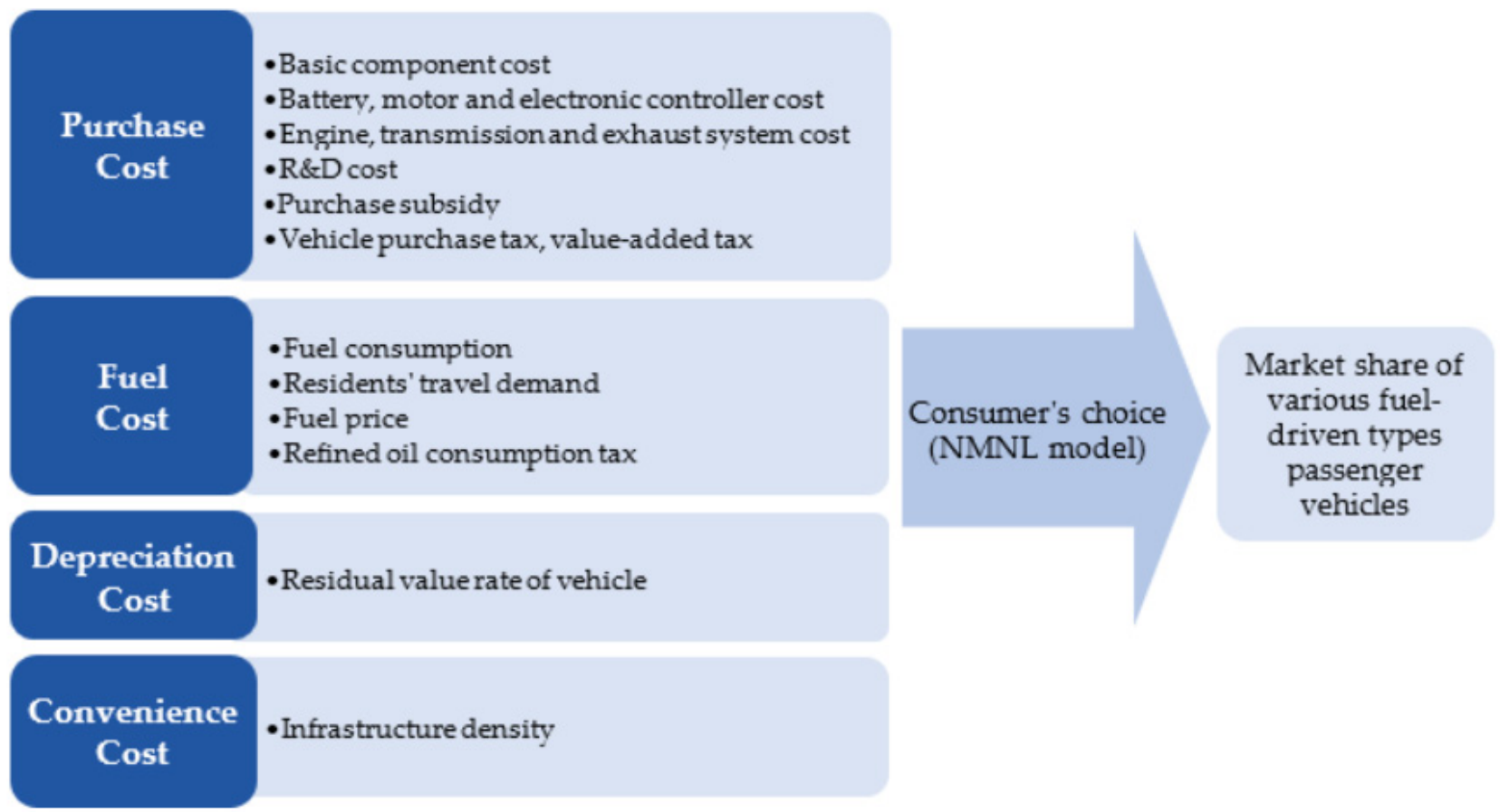

Figure 3. NMNL model flow chart. Note: The research object is A-class passenger vehicles of various fuel-driven types. For specific model examples, refer to BYD Qin Pro (ICEV/BEV/PHEV), and other fuel-driven types are also assumed to be typical A-class passenger vehicles of that fuel type.

Fuel cost: It refers to the total fuel cost that a consumer should pay during the use of the vehicle. Specifically, it includes fuel consumption rate, average annual travel demand and fuel price. In addition, it is necessary to consider the refined oil consumption tax levy plans for different scenarios in the future.

Depreciation cost: It refers to the expense lost when the consumer sells each model as a second-hand vehicle. Specifically, it can be expressed as a 1-residual value rate.

Convenience cost: It refers to the convenience or cost of refueling for each model. Here, the number of gas station infrastructure is 1 , while the relative value of the number of charging station facilities, number of gas station facilities and number of gas station facilities are deemed as the convenience cost of the remaining models.

\subsection{Model Building and Application}

This article takes the passenger vehicle market sales over the years as the overall consumer $\mathrm{N}$ and the historical sales of each model as the consumer $n$ who chooses the corresponding model. The NMNL model is used to simulate the decision-making process of the consumer in the overall market, calculate the probability of consumer choice and take it as the market share of each model in the future.

Using the NMNL model, passenger vehicles are firstly divided into three categories by fuel type: fuel oil, electric driven and alternative fuel. Then, the second subdivision is made by the technical route. The reasons for adopting this classification method are: (1) As the level of the nesting structure increases, the substitution of similar products should be stronger and the sensitivity to price should be higher. It is more consistent with the principle of nesting that the fuel type is regarded as the first-level nesting and all technical routes are regarded as second-level nesting. (2) Market research and related studies have confirmed that consumers have obvious prejudice against various fuel-driven types of models during the purchase process due to their personal preferences. The market share of each model is not entirely determined by quantitative indicators, while this prejudice is particularly obvious between fuel vehicles and NEVs. According to the fuel type, the models with similar price, performance and market acceptance are classified into the 
same category. Consumers can choose models at different levels and the result is more reasonable $[60,61]$.

Label the above seven models in sequence from top to bottom and from left to right in Figure 4 as Model 1 to Model 7, label the fuel types from left to right as 1 to 3, and mark the fuel type corresponding to $k$ models as $t_{k}$, then:

$$
t_{1}=t_{2}=1, t_{3}=t_{4}=2, t_{5}=t_{6}=t_{7}=3
$$

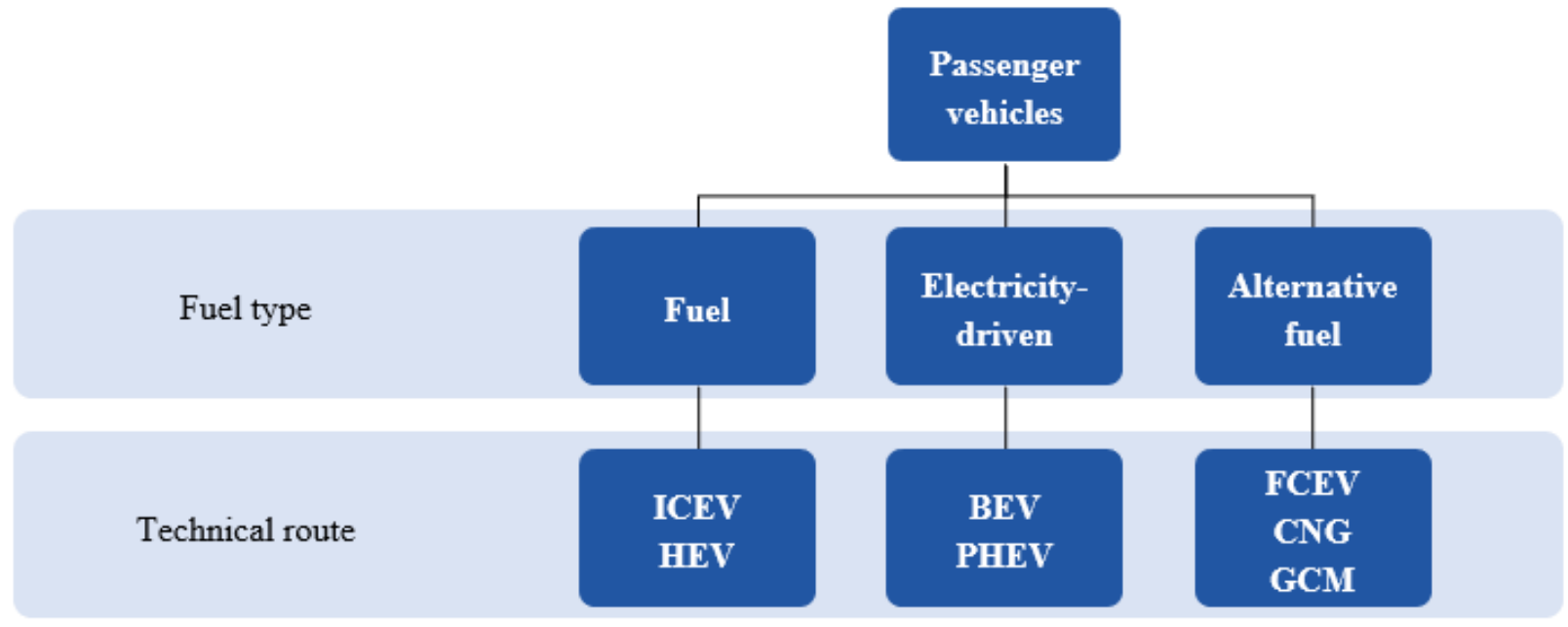

Figure 4. Structure of the NMNL model.

Record the four costs of the $k$-th vehicle model as $\vec{x}_{k}$, then the probability that the consumer $n$ chooses the $k$-th vehicle model in the model is:

$$
P_{n k}=P_{n h_{i}} \times P_{n k \mid h_{i}}=\frac{\sum_{j: t_{j}=t_{k}} e^{\vec{\beta}_{t_{j}} \vec{x}_{j}}}{\sum_{r=1}^{3} \sum_{j: t_{j}=r} e^{\vec{\beta}_{t_{j}} \vec{x}_{j}}} \times \frac{e^{\vec{\beta}_{t_{k}} \vec{x}_{k}}}{\sum_{j: t_{j}=t_{k}} e^{\vec{\beta}_{t_{j}} \vec{x}_{j}}}=\frac{e^{\vec{\beta}_{t_{k}} \vec{x}_{k}}}{\sum_{j=1}^{7} e^{\vec{\beta}_{t_{j}} \vec{x}_{j}}}
$$

where: $\vec{\beta}_{1}, \vec{\beta}_{2}, \vec{\beta}_{3}$ are the parameter vectors to be estimated, which respectively correspond to the utility weights of the four costs of the first to third fuel types of models, While the differences among them correspond to the consumer preference of different fuel types. The value of $P_{n k}$ in the above formula has nothing to do with $n$, so $P_{n k}$ is abbreviated as $P_{k}$. The parameters in the model can be estimated using the method of maximum likelihood estimation based on the data of previous years.

Considering that the data for each year includes all costs, total sales of each model in that year $N$ and the sales of a single model $n_{i}$, if the model purchased by the $n$th consumer is recorded as $y_{n}$, according to the model assumptions, $y_{n}$ follows the discrete distribution, the value range is $\{1,2,3,4,5,6,7\}$ and the probability of taking $k$ is $P_{k}$. According to $n_{k}=\sum_{n=1}^{N} I\left(y_{n}=k\right)$ and the independence among consumer choices, it can be concluded that $\left(n_{1}, \ldots, n_{7}\right)$ obeys a multinomial distribution and its density function is:

$$
p\left(n_{1}, \ldots, n_{7}\right)=\frac{N !}{\prod_{k=1}^{7} n_{k} !} \prod_{k=1}^{7} n_{k}^{P_{k}}
$$

The likelihood function is the part that contains the parameters after the logarithm of the density function, namely:

$$
l\left(\vec{\beta}_{1}, \vec{\beta}_{2}, \vec{\beta}_{3}\right)=\sum_{k=1}^{7} P_{k} \times \log \left(n_{k}\right)
$$


This parameter is included in all $P_{k}$. Based on all costs and sales for each year, the likelihood function corresponding to the data of the current year can be obtained. The likelihood function corresponding to all data in previous years is the sum of the likelihood functions of each previous year, which includes all the information of previous years. So, the obtained estimate is also the most explanatory. Finally, the likelihood function is:

$$
L\left(\vec{\beta}_{1}, \vec{\beta}_{2}, \vec{\beta}_{3}\right)=\sum_{\text {Year }=2013}^{2020} \sum_{k=1}^{7} P_{k} \times \log \left(n_{k}\right)
$$

Maximum likelihood estimation is a parameter estimation that maximizes the likelihood function. Its statistical significance is the value of the parameter that maximizes the probability of occurrence of events that have occurred in the past. In the process of using statistical software to solve the maximum point of the likelihood function, all parameter estimates can be obtained, that is, the utility weight of each cost and the consumer preference by vehicle model. According to the estimated values of these parameters, the data of any year is brought into the $P_{k}$ solution formula to obtain the probability of choosing each vehicle model in that year by a consumer, and use this as an estimate of the market share of each vehicle model to fit and evaluate the model results. Based on the real values, the technology and cost trends of each technical route are set and the market share forecast under the basic scenario is obtained. It also further predicts the market share that each fuel type of model can reach under the comprehensive implementation of various policies and realizes the quantification and effect evaluation of policies by changing policy scenarios and comparing the changes in market structure in different scenarios.

\section{Research Conclusions}

\subsection{Assumptions of Policy Scenarios}

Set up comprehensive policy scenarios, consider supply-side control policies and demand-side fiscal and taxation policies. The supply-side mainly focuses on fuel consumption regulations and NEV points requirements, while the demand side mainly focuses on the vehicle purchase tax policy affecting the purchase cost and the refined oil consumption tax policy affecting the use cost.

Assuming that the impact of fuel consumption regulations and points compliance policies are under consideration, manufacturers will meet the point ratio requirements in the future, NEV purchase tax incentives will gradually decline after 2024 and the refined oil consumption tax rate will gradually be increased after 2026. Fuel consumption of fuel-driven vehicles has continued to decline under the influence of fuel consumption regulations, while engine costs have continued to rise; the speed of R\&D cost allocation for NEVs has increased significantly, while the cost of fuel convenience has decreased significantly. The current relevant policy regulations and assumptions for future policy are shown in Table 3.

\subsection{Analysis of Model Results}

It is predicted that the proportion of NEVs in the passenger vehicle market is expected to increase from the current $6.2 \%$ to $50 \%$ in 2035 under the background of the above fuel consumption regulations, point requirements, subsidies and tax policy plans. Specifically, due to the low cost of use, high residual value rate, the release of purchase limits and traffic restrictions, higher consumer acceptance and other factors, the market share of PHEVs will significantly increase in the short term; after 2025, BEVs will have comprehensive advantages and will show an obvious development trend. Due to the increase in purchase cost and fuel cost of conventional vehicle models, the market share has significantly declined and HEV has become an alternative choice for ICEV consumers. The forecast of the proportion of sales of passenger vehicles by fuel type is shown in Table 4 and Figure 5. 
Table 3. Automotive industry-related policies and future scenarios that may be mainly considered in the model.

\begin{tabular}{|c|c|c|c|c|c|}
\hline Policy Category & -2022 & -2024 & -2025 & -2030 & -2035 \\
\hline Management & $\begin{array}{l}\text { (In 2025, 2030, a } \\
\text { (NEV credits w }\end{array}$ & $\begin{array}{l}\text { Ener } \\
\text { 2035, the average } \mathrm{f}\end{array}$ & $\begin{array}{l}\text { consumption target } \\
1 \text { consumption of pas } \\
\text { FC } / 100 \mathrm{~km}, 4.0 \mathrm{~L} / 100 \\
\mathrm{FC} \text { and NEV dual cre } \\
12 \% \text { in } 2020 \text { to } 50^{\circ}\end{array}$ & $\begin{array}{l}\text { etting } \\
\text { enger vehicles will } r \\
\text { m) } \\
\text { lit } \\
\text { in } 2035 \text {, increasing }\end{array}$ & $\begin{array}{l}\text { ch } 5.6 \mathrm{~L} / 100 \mathrm{~km} \text {, } \\
2-3 \% \text { per year) }\end{array}$ \\
\hline Subsidy & $\begin{array}{l}\text { Purchase subsidy } \\
\text { (Implemented } \\
\text { according to the } \\
\text { published policy, } \\
\text { ending in 2022) }\end{array}$ & $\begin{array}{lllllllll} & 0\end{array}$ & & & \\
\hline Taxes & $\begin{array}{l}\text { Exemption from } \\
\text { vehicle purchase } \\
\text { tax } \\
\text { (Exempted } \\
\text { according to the } \\
\text { published policy) }\end{array}$ & $\begin{array}{l}\text { Concessions to } \\
\text { vehicle purchase } \\
\text { tax } \\
\text { (Continue to be } \\
\text { exempted) }\end{array}$ & $\begin{array}{l}\text { Concessions to } \\
\text { vehicle purchase } \\
\text { tax } \\
\text { (Vehicle purchase } \\
\text { tax rate increases } \\
\text { by } 2 \% \text { per year) }\end{array}$ & $\begin{array}{l}\text { Vehicle purchase } \\
\text { tax and } \\
\text { consumption tax } \\
\text { incentives based } \\
\text { on energy } \\
\text { efficiency } \\
\text { indicators } \\
\text { (Vehicle purchase } \\
\text { tax rate will } \\
\text { increase by } 2 \% \\
\text { every year until } \\
10 \% \text {, excise tax is } \\
\text { exempted) } \\
\text { * Increase in fuel } \\
\text { tax } \\
\text { (Tax amount } \\
\text { increased by } 5 \% \text { ) }\end{array}$ & $\begin{array}{l}\text { Vehicle purchase } \\
\text { tax and } \\
\text { consumption tax } \\
\text { incentives based } \\
\text { on energy } \\
\text { efficiency } \\
\text { indicators } \\
\text { (Start to levy excise } \\
\text { tax on BEVs and } \\
\text { FCEVs) } \\
\text { * Increase in fuel } \\
\text { tax } \\
\text { (Tax amount } \\
\text { increased by } 5 \% \text { ) }\end{array}$ \\
\hline
\end{tabular}

Note: The lightness of the color in the table represents the degree of implementation of the policy. The darker the color, the greater the degree of implementation. Without * is a reward system, while with * is a punitive system.

Table 4. Forecast of the proportion of sales of passenger vehicles by fuel type.

\begin{tabular}{ccccc}
\hline Year & Non-NEV & BEV & PHEV & FCEV \\
\hline 2020 & $93.8 \%$ & $4.9 \%$ & $1.2 \%$ & $0.0 \%$ \\
2025 & $80.0 \%$ & $13.0 \%$ & $7.0 \%$ & $0.0 \%$ \\
2030 & $59.1 \%$ & $29.1 \%$ & $11.8 \%$ & $0.0 \%$ \\
2035 & $50.0 \%$ & $38.7 \%$ & $11.2 \%$ & $0.1 \%$ \\
\hline
\end{tabular}

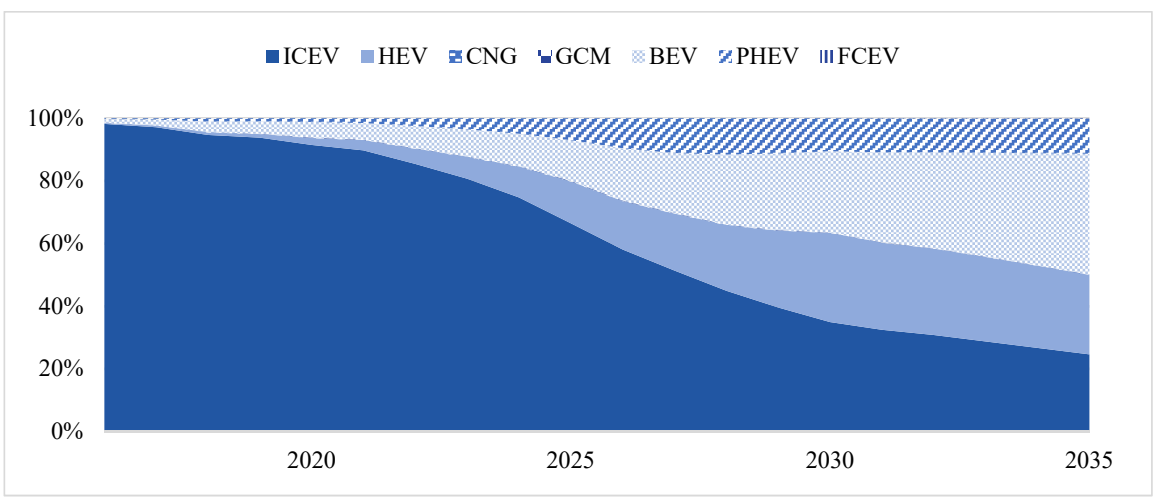

Figure 5. Forecast of the proportion of sales of passenger vehicles by fuel type.

\subsection{Sensitivity Analysis of Influencing Factors}

This article analyzes the impact of various policy programs on the structure of the automotive market in the future: 
Consumers are most sensitive to the adjustment of the refined oil consumption tax rate. Small changes in the tax amount will cause consumers to pay additional fuel costs in the process of use $\mathrm{k}$. The improvement in refined oil consumption tax will effectively increase the market share of NEVs.

The adjustment of vehicle purchase tax policy also has an impact. Comparing the two scenarios of the gradual decline of the NEVs purchase tax after 2022 and maintenance of such tax exemption, the NEVs purchase tax did slightly inhibit the rapid growth of the NEV market.

The decline in battery cost caused by the technological upgrade of BEVs and PHEVs will also effectively boost the increase in the proportion of the sales of NEVs. Finally, convenience cost is particularly concerned by consumers.

\section{Policy Recommendations}

The popularization of NEVs requires more cost reduction measures. This paper analyzes the probability of consumers choosing different fuel types of passenger vehicles from the perspective of the cost of owning a vehicle. The supply-side policy increases the cost of fuel-driven vehicles and reduces the cost of NEVs. At the same time, as new energy passenger vehicle technology progresses and scale growth has further reduced costs, new energy passenger vehicles gradually occupy a small market share. In the future, it is required to make consideration based on costs to further promote the development of NEVs: on the one hand, enterprises are required to accelerate the reduction of model costs through technological advancement and scale expansion; on the other hand, the government is required to adopt policies to influence the changes in the cost of each model in the whole life cycle.

Different application scenarios are applicable for the vehicles at different technical routes. The cost of fuel vehicles continuously increases under the influence of supplyside management policies. At the same time, with the consumer-side NEVs incentive policies, ICEV's market share will gradually decline. However, HEVs have a relatively large market share due to their good energy-saving and emission-reduction advantages. With the gradual reduction of manufacturing costs and the use of cost, the market share of BEVs is gradually expanding. As PHEVs are not subject to purchase limits and traffic restrictions and have a low cost of use, PHEVs will still have a certain market share in the future. If the convenience of charging is significantly improved, the market share of PHEVs may decline significantly. The cost of FCEVs is still high by 2035, so their market share is expected to be less than $1 \%$.

In the financial incentive policy plan after 2022, this article recommends a policy plan to gradually impose vehicle purchase tax on NEVs after 2024, increase the fuel tax rate in stages after 2025, and impose an excise tax on BEVs and FCEVs after 2030. The plan can not only ensure the stability of NEVs support but also enable the gradual reduction of financial investment. When the various policies are connected, the plan has less effect on market volatility.

Author Contributions: Conceptualization, K.L. and B.L.; methodology, K.L.; software, K.L.; validation, K.L. and H.S.; formal analysis, K.L.; resources, H.S.; data curation, K.L. and H.S.; writingoriginal draft preparation, K.L. and B.L.; writing-review and editing, H.S. and B.L.; project administration, X.J.; All authors have read and agreed to the published version of the manuscript.

Funding: This research was funded by the National Key Research and Development Program of the Ministry of Science and Technology of China "Joint research on advanced technologies of electric vehicles for sino-us cooperation", grant number 2019YFE0100200.

Conflicts of Interest: The authors declare no conflict of interest. Both authors are employees of China Automotive Technology and Research Center. The paper reflects the views of the scientists, and not the company. 


\section{References}

1. Energy-Saving and New Energy Automobile Industry Development Plan (2012-2020). Available online: http://www.gov.cn/ gongbao/content/2012/content_2182749.htm (accessed on 25 September 2021).

2. National High-Tech Research and Development Program (863 Program). Available online: http://www.most.gov.cn/ztzl/ swkjjh/kjjhjj/200610/t20061021_36375.html (accessed on 25 September 2021).

3. 11th Five-Year Development Outline of the National Science and Technology Support Plan. Available online: http:/ www.most. gov.cn/ztzl/qgkjgzhy/2007/2007syw/200702/t20070214_41340.html (accessed on 25 September 2021).

4. Notice on Organizing the Development of Technological Innovation Projects in the New Energy Automobile Industry. Available online: http:/ / www.gov.cn/gzdt/2012-10/12/content_2242395.htm (accessed on 25 September 2021).

5. Interim Measures for the Administration of National Key R\&D Programs. Available online: http://www.most.gov.cn/xxgk/ xinxifenlei/fdzdgknr/fgzc/gfxwj/gfxwj2017/201706/t20170628_133796.html (accessed on 25 September 2021).

6. Auto Industry Adjustment and Revitalization Plan. Available online: http://www.gov.cn/zwgk/2009-03/20/content_1264324. htm (accessed on 25 September 2021).

7. Mid- to Long-Term Development Plan for the Automotive Industry. Available online: http://www.gov.cn/gongbao/content/20 17/ content_5230289.htm (accessed on 25 September 2021).

8. New Energy Automobile Industry Development Plan (2021-2035). Available online: http://www.gov.cn/zhengce/content/2020 -11/02/content_5556716.htm (accessed on 25 September 2021).

9. Notice on Further Improving the Financial Subsidy Policy for the Promotion and Application of New Energy Vehicles. Available online: http:/ /jjs.mof.gov.cn/zhengcefagui/202012/t20201231_3638812.htm (accessed on 25 September 2021).

10. Notice on Improving the Price Subsidy Policy of Refined Oil for Urban Buses and Accelerating the Promotion and Application of New Energy Vehicles. Available online: http:/ / www.gov.cn/xinwen/2015-05/22/content_2866789.htm (accessed on 25 September 2021).

11. Notice on Adjusting and Improving the Consumption Tax Policy. Available online: http://www.chinatax.gov.cn/chinatax/n360 / c612/ content.html (accessed on 30 October 2021).

12. Notice on Energy-Saving New Energy Vehicles and Ships Enjoying Vehicle and Ship Tax Preferential Policies. Available online: http:/ / www.chinatax.gov.cn/n810341/n810755/c3640048/content.html (accessed on 30 October 2021).

13. Announcement on the New Energy Vehicle Purchase Tax Exemption Policy. Available online: http://www.chinatax.gov.cn/ chinatax/n810341/n810755/c5148808/content.html (accessed on 30 October 2021).

14. Announcement on Adjusting the Technical Requirements for New Energy Vehicle Products Exempted from Vehicle Purchase Tax. Available online: https:/ /ythxxfb.miit.gov.cn/ythzxfwpt/hlwmh/tzgg/xzxk/clsczr/art/2021/art_a77258175f0141b18e88f050 546155dd.html (accessed on 30 October 2021).

15. Notice on Issues Related to Electric Vehicle Electricity Price Policy. Available online: https://www.ndrc.gov.cn/fggz/tzgg/ggkx/ 201408/t20140806_1073810.html (accessed on 30 October 2021).

16. Guidelines for the Development of Electric Vehicle Charging Infrastructure (2015-2020). Available online: http:/ / www.gov.cn/ zhengce/2015-10/09/content_5076250.htm (accessed on 30 October 2021).

17. Notice on Rewards for the Construction of New Energy Vehicle Charging Facilities. Available online: http://www.gov.cn/ xinwen/2014-11/26/content_2783831.htm (accessed on 30 October 2021).

18. Notice on the "13th Five-Year" New Energy Vehicle Charging Infrastructure Incentive Policy and Strengthen the Promotion and Application of New Energy Vehicles. Available online: http://www.gov.cn/xinwen/2016-01/20/content_5034655.htm (accessed on 30 October 2021).

19. Action Plan for Improving the Charging Capability of New Energy Vehicles. Available online: http://www.gov.cn/xinwen/2018 -12/10/content_5347391.htm (accessed on 30 October 2021).

20. Regulations on Management of New Energy Vehicle Production Enterprises and Product Access. Available online: http: / / www.gov.cn/xinwen/2020-08/19/content_5535780.htm (accessed on 30 October 2021).

21. Special Administrative Measures for Foreign Investment Access (Negative List) (2018 Edition). Available online: http:/ /www mofcom.gov.cn/article/b/f/201806/20180602760432.shtml (accessed on 1 November 2021).

22. Decision on Revising the "Measures for the Parallel Management of Average Fuel Consumption of Passenger Car Companies and New Energy Vehicle Credits". Available online: http:/ / www.gov.cn/zhengce/zhengceku/2020-06/22/content_5521144.htm (accessed on 1 November 2021).

23. Li Keqiang Presided over the Executive Meeting of the State Council. Available online: http://www.gov.cn/guowuyuan/2015-0 9/29/content_2940663.htm (accessed on 1 November 2021).

24. Promote the Renewal and Upgrade of Key Consumer Products and Unblock Resource Recycling Implementation Plan (2019-2020). Available online: http://www.gov.cn/xinwen/2019-06/07/content_5398219.htm (accessed on 1 November 2021).

25. The Traffic Management Bureau of the Ministry of Public Security Deploys the Comprehensive Promotion of Special License Plates for New Energy Vehicles. Available online: http://www.gov.cn/xinwen/2017-11/18/content_5240710.htm (accessed on 1 November 2021).

26. Notice on Improving the Fiscal Subsidy Policy for the Promotion and Application of New Energy Vehicles. Available online: http:/ /jjs.mof.gov.cn/zhengcefagui/202004/t20200423_3502975.htm (accessed on 1 November 2021).

27. Koning, R.H.; Ridder, G. Discrete choice and stochastic utility maximization. Econom. J. 2003, 6, 1-27. [CrossRef] 
28. Transport Research Laboratory. D2.1. Consumer Attitudes and Behaviours Report, The Future of Transport Report. Available online: https: / / esc-non-prod.s3.eu-west-2.amazonaws.com/2020/12/CVEI-Consumer-attitudes-and-behaviours-report.pdf (accessed on 1 November 2021).

29. Yan, S. The economic and environmental impacts of tax incentives for battery electric vehicles in Europe. Energy Policy 2018, 123, 53-63. [CrossRef]

30. Di Foggia, G. Drivers and challenges of electric vehicles integration in corporate fleet: An empirical survey. Res. Transp. Bus. Manag. 2021. [CrossRef]

31. Wang, N.; Tang, L.; Pan, H. A global comparison and assessment of incentive policy on electric vehicle promotion. Sustain. Cities Soc. 2019, 44, 597-603. [CrossRef]

32. Nie, Y.; Ghamami, M.; Zockaie, A.; Xiao, F. Optimization of incentive polices for plug-in electric vehicles. Transp. Res. Part B Methodol. 2016, 84, 103-123. [CrossRef]

33. Potoglou, D.; Kanaroglou, P.S. Household demand and willingness to pay for clean vehicles. Transp. Res. Part D Transp. Environ. 2007, 12, 264-274. [CrossRef]

34. Gallagher, K.S.; Muehlegger, E. Giving green to get green? Incentives and consumer adoption of hybrid vehicle technology. J. Environ. Econ. Manag. 2011, 61, 1-15. [CrossRef]

35. Manski, C.F.; Sherman, L. An empirical analysis of household choice among motor vehicles. Transp. Res. Part A Gen. 1980, 14, 349-366. [CrossRef]

36. Ewing, G.O.; Sarigöllü, E. Car fuel-type choice under travel demand management and economic incentives. Transp. Res. Part D Transp. Environ. 1998, 3, 429-444. [CrossRef]

37. Brownstone, D.; Bunch, D.S.; Train, K. Joint mixed logit models of stated and revealed preferences for alternative-fuel vehicles. Transp. Res. Part B Methodol. 2000, 34, 315-338. [CrossRef]

38. Berkovec, J. Forecasting automobile demand using disaggregate choice models. Transp. Res. Part B Methodol. 1985, 19, 315-329. [CrossRef]

39. Berkovec, J.; Rust, J. A nested logit model of automobile holdings for one vehicle households. Transp. Res. Part B Methodol. 1985, 19, 275-285. [CrossRef]

40. Bunch, D.S.; Bradley, M.; Golob, T.F.; Kitamura, R.; Occhiuzzo, G.P. Demand for clean-fuel vehicles in California: A discrete-choice stated preference pilot project. Transp. Res. Part A Policy Pract. 1993, 27, 237-253. [CrossRef]

41. Ardeshiri, A.; Rashidi, T.H. Willingness to pay for fast charging station for electric vehicles with limited market penetration making. Energy Policy 2020, 147, 111822. [CrossRef]

42. Gong, S.; Ardeshiri, A.; Rashidi, T.H. Impact of government incentives on the market penetration of electric vehicles in Australia. Transp. Res. Part D Transp. Environ. 2020, 83, 102353. [CrossRef]

43. Abotalebi, E.; Scott, D.M.; Ferguson, M.R. Ferguson, Why is electric vehicle uptake low in Atlantic Canada? A comparison to leading adoption provinces. J. Transp. Geogr. 2019, 74, 289-298. [CrossRef]

44. Axsen, J.; Goldberg, S.; Bailey, J. How might potential future plug-in electric vehicle buyers differ from current "Pioneer" owners? Transp. Res. Part D Transp. Environ. 2016, 47, 357-370. [CrossRef]

45. Ferguson, M.; Mohamed, M.; Higgins, C.D.; Abotalebi, E.; Kanaroglou, P. How open are Canadian households to electric vehicles? A national latent class choice analysis with willingness-to-pay and metropolitan characterization. Transp. Res. Part D Transp. Environ. 2018, 58, 208-224. [CrossRef]

46. Kormos, C.; Axsen, J.; Long, Z.; Goldberg, S. Latent demand for zero-emissions vehicles in Canada (Part 2): Insights from a stated choice experiment. Transp. Res. Part D Transp. Environ. 2019, 67, 685-702. [CrossRef]

47. Huang, Y.; Qian, L. Consumer preferences for electric vehicles in lower tier cities of China: Evidences from south Jiangsu region. Transp. Res. Part D Transp. Environ. 2018, 63, 482-497. [CrossRef]

48. Ma, S.C.; Xu, J.H.; Fan, Y. Willingness to pay and preferences for alternative incentives to EV purchase subsidies: An empirical study in China. Energy Econ. 2019, 81, 197-215. [CrossRef]

49. Qian, L.; Grisolía, J.M.; Soopramanien, D. The impact of service and government-policy attributes on consumer preferences for electric vehicles in China. Transp. Res. Part A Policy Pract. 2019, 122, 70-84. [CrossRef]

50. Wang, N.; Tang, L.; Pan, H. Effectiveness of policy incentives on electric vehicle acceptance in China: A discrete choice analysis. Transp. Res. Part A Policy Pract. 2017, 105, 210-218. [CrossRef]

51. Hackbarth, A.; Madlener, R. Willingness-to-pay for alternative fuel vehicle characteristics: A stated choice study for Germany. Transp. Res. Part A Policy Pract. 2016, 85, 89-111. [CrossRef]

52. Danielis, R.; Rotaris, L.; Giansoldati, M.; Scorrano, M. Drivers' preferences for electric cars in Italy. Evidence from a country with limited but growing electric car uptake. Transp. Res. Part A Policy Pract. 2020, 137, 79-94. [CrossRef]

53. Orlov, A.; Kallbekken, S. The impact of consumer attitudes towards energy efficiency on car choice: Survey results from Norway. J. Clean. Prod. 2019, 214, 816-822. [CrossRef]

54. Choi, H.; Shin, J.; Woo, J. Effect of electricity generation mix on battery electric vehicle adoption and its environmental impact. Energy Policy 2018, 121, 13-24. [CrossRef]

55. Langbroek, J.H.; Franklin, J.P.; Susilo, Y.O. The effect of policy incentives on electric vehicle adoption. Energy Policy 2016, 94, 94-103. [CrossRef] 
56. Cirillo, C.; Liu, Y.; Maness, M. A time-dependent stated preference approach to measuring vehicle type preferences and market elasticity of conventional and green vehicles. Transp. Res. Part A Policy Pract. 2017, 100, 294-310. [CrossRef]

57. Hagman, J.; Ritzén, S.; Stier, J.J.; Susilo, Y. Total cost of ownership and its potential implications for battery electric vehicle diffusion. Res. Transp. Bus. Manag. 2016, 18, 11-17. [CrossRef]

58. Zhang, T.; Gensler, S.; Garcia, R. A Study of the Diffusion of Alternative Fuel Vehicles: An Agent-Based Modeling Approach. J. Prod. Innov. Manag. 2011, 28, 152-168. [CrossRef]

59. Lévay, P.Z.; Drossinos, Y.; Thiel, C. The effect of fiscal incentives on market penetration of electric vehicles: A pairwise comparison of total cost of ownership. Energy Policy 2017, 105, 524-533. [CrossRef]

60. Wong, R.C.; Szeto, W.Y.; Wong, S.C. Behavior of taxi customers in hailing vacant taxis: A nested logit model for policy analysis. J. Adv. Transp. 2016, 49, 867-883. [CrossRef]

61. Tanaka, M.; Ida, T.; Murakami, K.; Friedman, L. Consumers' willingness to pay for alternative fuel vehicles: A comparative discrete choice analysis between the US and Japan. Transp. Res. Part A Policy Pract. 2014, 70, 194-209. [CrossRef] 